\title{
SISTEM PAKAR UNTUK DETEKSI PENYAKIT PADA TERNAK BABI DENGAN MENGGUNAKAN METODE FUZZY TSUKAMOTO
}

\author{
AAA Putri Ardyanti ${ }^{1)}$ IGAN Indra Adnyana ${ }^{2)}$ I Nyoman Purnama $^{3)}$ \\ Program Studi Teknik Informatika ${ }^{12) 3 \text { ) }}$ \\ STMIK Primakara, Denpasar, Bali ${ }^{1)}$ 2) 3) \\ putri.ardyanti@ primakara.ac.id ${ }^{1)}$ ngurahindraadnyana@gmail.com ${ }^{2)}$
}

\begin{abstract}
Expert systems allow the process of communication between doctors and breeders can be done without having to do face-to-face directly. One reason for the importance of developing this application is meningitis in humans that occurred massively in Bali in February 2017. The initial step of this research is knowledge acquisition where first interviewing experts in the field of pig disease, continued representation of knowledge before being modeled into mathematical calculation formulas, which will later be added Fuzzy method, through modeling definite symptoms, syndrome symptoms, and Fuzzy symptoms, in inference Fuzzy rules will be made fuzzification and calculation of the certainty factor. After programming the system, the system test will be carried out in 3 stages, namely interviewing again with the implementation of the system, testing the results by looking for the value of instrument reliability, and finally the analysis of the results of tests carried out on several pig farms. An expert system for diagnosing pig disease has been developed by combining fuzzy logic methods to deal with the uncertainty of symptoms experienced by pigs and the inability of an expert to definitively define the relationship between symptoms and disease. The value of the accuracy of disease consultation in pigs is obtained from the average value of the success of the system of finding diseases in pigs, namely $85 \%$.
\end{abstract}

Keywords: Fuzzy, Expert System, Tsukamoto, Pig disease

\begin{abstract}
ABSTRAK
Sistem pakar memungkinkan proses komunikasi antara dokter dan peternak dapat dilakukan tanpa harus melakukan tatap muka secara langsung. Salah satu alasan pentingnya pengembangan aplikasi ini adalah penyakit meningitis pada manusia yang terjadi secara masal di Bali pada bulan Februari 2017.Langkah awal penelitian ini adalah akuisi pengetahuan dimana terlebih dahulu melakukan wawancara kepada pakar dibidang penyakit babi, dilanjutkan representasi pengetahuan tersebut sebelum dimodelkan kedalam rumus perhitungan matematika, yang nantinya akan ditambahkan metode Fuzzy, melalui pemodelan gejala pasti, gejala sindrom, dan gejala Fuzzy, pada inferensi Fuzzy akan dilakukan aturan- aturan fuzzifikasi dan dilakukan perhitungan factor kepastian. Setelah pemograman sistem maka uji sistem akan dilakukan dengan 3 tahapan yaitu wawancara kembali dengan implementasi sistem, uji hasil dengan mencari nilai reliabitas instrumen, dan terakhir adalah analisis uji hasil yang dilakukan ke beberapa peternakan babi. Sistem pakar untuk diagnosa penyakit babi telah dikembangkan dengan menggabungkan metode logika fuzzy untuk menangani ketidakpastian gejala yang dialami oleh ternak babi dan ketidakmampuan seorang pakar dalam mendefinisikan hubungan antara gejala dan penyakit secara pasti. Nilai ketepatan dari konsultasi penyakit pada ternak babi didapatkan dari nilai rata-rata keberhasilan sistem menemukan penyakit pada babi yaitu $85 \%$.
\end{abstract}

Kata kunci: fuzzy, sistem pakar, tsukamoto, penyakit babi. 


\section{PENDAHULUAN}

Pada tahun 2005 di Cina terjadi bencana dimana kematian ternak babi meningkat hingga $135 \%$ dalam kurun waktu 2 tahun, hal ini dikarenakan karena berbagai penyakit babi. Departemen peternakan dan pertanian pada waktu itu meminta bantuan dari para pakar penyakit babi, akan tetapi pada waktu itu para ahli jarang dan tidak bersedia pergi memeriksa ternak yang mati, terutama didaerah pedesaan, untuk melakukan sebuah cara efektif untuk mendiagnosis, merawat dan mencegah penyakit babi dibutuhkan sebuah aplikasi yang pintar dan mampu belajar seperti seorang pakar. Bila seekor babi telah menunjukan gejala penyakit, pentingnya sebuah aplikasi sistem yang mampu mediagnosis secara akurat. Strategi pengendalian diagnosis penyakit babi memerlukan keahlian yang cukup banyak dan hanya sedikit pakar yang mampu melakukannya [1].

Sistem pakar babi pertama kali di Cina bernama Pig-Vet dikembangkan oleh Cina Agricultural University hanya mampu mendiagnosis 54 jenis penyakit umum babi dan telah diujicobakan di utara Cina [2] dalam penelitiannya berjudul "An IDSS Supported by Semantic Technology: a Study for Pig Disease Diagnosis Management", dimana sistem dapat memberikan saran diagnosis penyakit secara tepat waktu dan secara efektif berdasarkan informasi yang diberikan oleh pengguna, seperti kondisi fisik babi, gejala atau lingkungan.

\section{TINJAUAN PUSTAKA \\ Penyakit Pada Babi}

Menurut Ardana [3] manajemen pengobatan babi sakit ditujukan untuk menghindari kerugian akibat kematian babi yang sebelumnya menderita penyakit. Sebaliknya, tindakan rehabilitasi ditujukan untuk pemulihan kondisi babi setelah sakit. Berdasarkan penyebabnya, penyakit pada babi dapat digolongkan menjadi dua kelompok, yaitu penyakit infeksi dan noninfeksi. Kedua kelompok tersebut dapat menyerang babi pada fase prasapih, grower, finisher, dan induk babi, baik pada saluran pernapasan, pencemaan, reproduksi, dan saluran kemih.
Fase lahir sampai dengan disapih, seperti keterlambatan melahirkan, kelemahan dan kelaparan, faktor fisiologi, kemacetan air susu induk, kekurangan kolostrum, anemia, defisiensi $\mathrm{Ca}$ dan $\mathrm{P}$, defisiensi $\mathrm{J}$ (iodine), infeksi umbilikus (pusar), serangan penyakit infeksi

Fase sapih sampai fattening adalah penyakit yang sering menyerang babi setelah sapih antara lain: Ascariasis, Trichuriasis, Oesofagustomiasis, Scabies, Erysipelas, Hog Cholera,Salmonellosis (8-16 minggu), Disentri Babi (Swine Dysentery): masa babi selama fase pertumbuhan dan hewan dewasa, jamur dan penyakit mulut kuku (PMK).

Penyakit pada Induk, yaitu Milk fever, Farrowing fever (demam saat beranak), Mastitis. Penyakit Pernapasan pada Babi berdasarkan penyebabnya, digolongkan tiga kelompok penyakit. Penyakit yang disebabkan oleh bakteri antara lain: Streptococcusis (Streptococcus suis), Pasteurellosis (Pasteurella multosida), Glasser disease (Hemophilus parasuis), APP (Actinobacillus pleuropneumoniae), dan PRDC (Mycoplasma hyopneumoniae).

Penyakit yang disebabkan oleh virus antara lain: PRRS (PRRS virus), PCV II (Porcine Circovirus), SIV (Swine Influenza virus), dan PRV (Pseudorabies virus). Penyakit yang disebabkan oleh parasit antara lain Cacing paru-paru (lung worm), dan Cacing gilik (round worm $=$ Ascaris suum y, Larva-3).

Berikut ini diuraikan secara rinci beberapa yang umum menyerang ternak babi yang dipelihara didunia, termasuk di Bali, yaitu Colibacillosis, Coccidiosis, Ascariasis, Streptococcosis, Pasteurellosis, Glasser -S Disease, Actinobacillus Pleuropneumon, Enzootic Pneumonia - Ep (Mycoplasmosis)

Penelitian ini akan menggabungkan kepakaran dari beberapa sumber yaitu pakar dari Universitas Udayana

\section{Fuzzy Inference System}

Menurut Sivanandan dkk [4], sistem penalaran Fuzzy atau Fuzzy Inference System (FIS) merupakan unit utama pada sistem logika Fuzzy dengan bagian paling penting adalah unit pembuat keputusan. FIS memformulasikan aturan-aturan yang sesuai dan keputusan dibuat berdasarkan aturanaturan tersebut. 
Cara kerja FIS adalah input tegas dikonversi ke Fuzzy dengan menggunakan metode fuzzifikasi. Setelah proses fuzzifikasi, akan dilakukan proses pembentukan basis aturan.

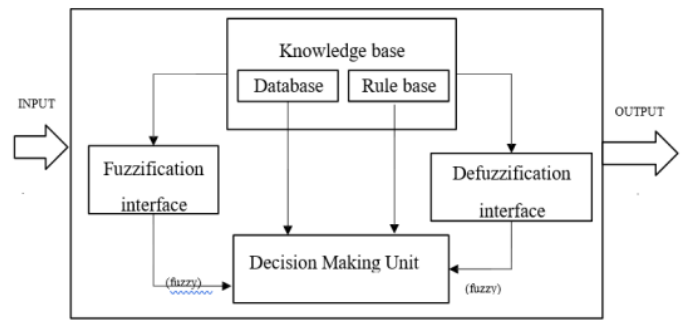

Gambar 1. Proses Fuzzifikasi [5]

\section{Metode Penalaran Fuzzy}

Data Menurut [6] [7], metode penalaran fuzzy untuk membentuk aturan fuzzy dari suatu himpunan data input - output , dengan format sebagai berikut:

IF $x$ is $A$ and $y$ is $B$ THEN $z=f(x, y)$

Untuk model fuzzy keluaran z merupakan konstanta $(\mathrm{a}=\mathrm{b}=\mathrm{c})$. Keluaran zi

setiap aturan diukur dengan mencari nilai bobot wi dari aturan tersebut, maka wi dapat diukur dengan :

wi $=$ ANDMethod (F1(x), F2(y))....(1)

Keluaran akhir dari sistem diperoleh melalui bobot rata-rata dari seluruh keluaran, dihitung

dengan:

Keluaran akhir $=\frac{\sum_{i=1}^{N} w_{i} z_{i}}{\sum_{i=1}^{N} w_{i}}$

\section{Faktor Kepastian}

Faktor kepastian (Certainty Factor-CF) diperkenalkan oleh Shortliffe Buchanan dalam pembuatan MYCIN. Faktor kepastian merupakan nilai parameter klinis yang diberikan MYCIN untuk menunjukan besarnya kepercayaan, didefinisikan sebagai berikut

$\mathrm{CF}(\mathrm{H}, \mathrm{E})=M \mathrm{~B}(\mathrm{H}, \mathrm{E})-\mathrm{MD}(\mathrm{H}, \mathrm{E})$

dimana:

$\mathrm{CF}(\mathrm{H}, \mathrm{E})$ faktor kepastian dari hipotesis $\mathrm{H}$ yang dipengaruhi oleh premis (evidence) $\mathrm{E}$ $\mathrm{MB}(\mathrm{H}, \mathrm{E}) \mathrm{ukuran}$ kepercayaan terhadap hipotesis $\mathrm{H}$ yang dipengaruhi oleh premis (evidence)E $\mathrm{MD}(\mathrm{H}, \mathrm{E})$ ukuran kepercayaan terhadap hipotesis $\mathrm{H}$ yang dipengaruhi oleh premis (evidence)E.

\section{Kerangka Konseptual Penelitian}

Berdasarkan tinjauan pustaka yang telah diuraikan, dapat disusun kerangka teori sebagai berikut:

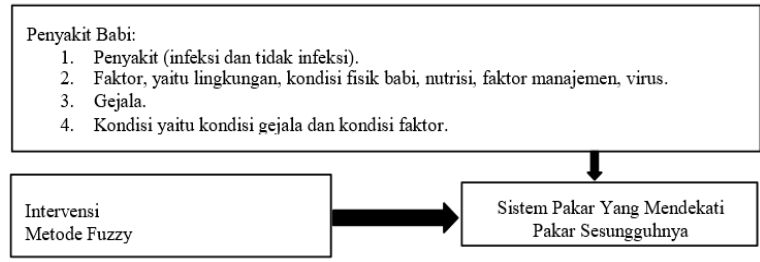

Gambar 2. Kerangka Penelitian

Penyakit pada ternak babi dikendalikan oleh peneliti pada kateria inklusi yaitu penyakit infeksi atau tidak terinfeksi pada 4 fase perkembangan penyakit babi. Faktor penyakit dikendalikan oleh peneliti pada kateria inklusi yaitu kondisi fisik, nutrisi, manajemen dan virus. Gejala penyakit dikendalikan peneliti pada kateria inklusi yaitu melalui pakar penyakit ba bi. Sosial budaya, ekonomi, lingkungan, dan jenis pelayanan kesehatan dikendalikan oleh peneliti dengan mengambil sampel dari satu lingkup yang sama yaitu sebuah peternakan babi. Sumber informasi dikendalikan oleh peneliti dengan menanyakan pada kuesioner apakah ada sumber informasi lain selain penyuluhan yang diberikan oleh peneliti. Kerangka Konsep berpikir dipengaruhi oleh penggunaan metode Fuzzy.

Hipotesis dari penelitian ini adalah sistem pakar yang telah diimplementasikan dan diuji oleh seorang pakar terhadap 20 kasus pengujian yang berbeda dan menghasilkan persentase yang tinggi terhadap kemiripan sistem pakar dengan pakar yang sesungguhnya. 


\section{METODOLOGI PENELITIAN Diagram alir}

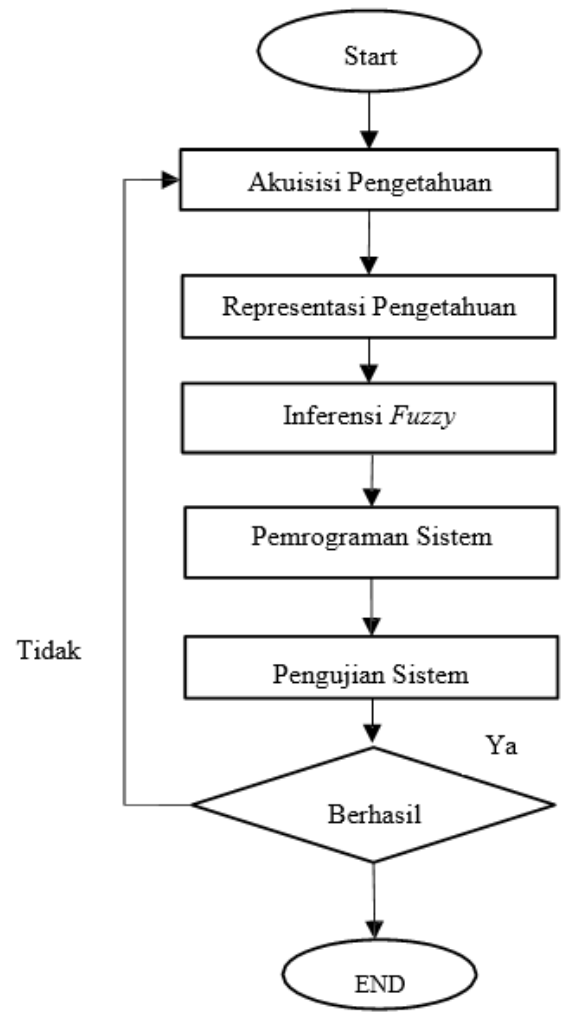

Gambar 3. Diagram Alir

\section{Metode Pengumpulan Data}

Adapun jenis pengumpulan data yang digunakan dalam penelitian sebagai berikut :

1. Observasi

2. Wawancara ( Interview )

3. Studi Pustaka

\section{Metodologi Penelitian}

Metode penelitian yang digunakan menggunakan kombinasi model sequential exploratory dimana metode ini menggabungkan metode penelitian dan pengembangan (research and development) yang biasa digunakan untuk mengembangkan dan menguji sistem. Penelitian dilakukan melalui dua tahapan, tahap pertama dengan metode kualitatif sehingga dapat diperoleh rancangan sistem dan penelitian tahap ke dua dengan metode kuantitatif (eksperimen) digunakan untuk menguji efektivitas sistem yang dihasilkan (Sugiyono, 2012).

\section{Analisis Kebutuhan Perangkat Keras}

PPemrograman sistem dan mesin penalaran yang telah dirancang digunakan untuk membuat aplikasi sistem pakar. Sistem ini dibangun berbasis web menggunakan beberapa piranti bantu perangkat lunak sebagai berikut:

a. SQLyog Ultimate untuk membuat basis pengetahuan dan basis penalaran

b. PHP, HTML dan CSS untuk membuat desain tampilan aplikasi sistem pakar.

c. Xampp untuk menjalanka

d. PHP, SQL dan Apache dalam server lokal

Dalam melakukan proses ini membutuhkan piranti bantu perangkat keras berupa computer personal dengan prosesor Intel Core i7-7500U dan memory 8 GB serta VGA 2GB shared.

\section{Arsitektur Sistem Pakar}

Sistem pakar yang dibangun dengan piranti bantu perangkat lunak pada proses pemrograman sistem memiliki arsitektur sistem yang terdiri dari dua komponen, yaitu komponen pengembangan dan konsultasi.

\section{Akuisisi Pengetahuan}

Akuisisi pengetahuan merupakan lingkungan pengembangan yang digunakan oleh perekayasa pengetahuan untuk mendapatkan pengetahuan dari pakar. Pada sistem pakar yang dibangun, pengetahuan diperoleh melalui studi literatur terhadap pustaka-pustaka ilmu ternak babi dan wawancara dengan peternak dan pakar ahli penyakit babi.

\section{Basis Pengetahuan}

Pada sistem pakar yang dibangun, basis pengetahuan di lingkungan pengembangan digunakan untuk menyimpan fakta dan aturan yang telah diperoleh pada proses akusisi pengetahuan. Basis pengetahuan untuk fakta sendiri dari delapan tabel yang telah dijabarkan diatas. 
Tabel 1 Fakta Gejala

\begin{tabular}{ll}
\hline Kode & Gejala \\
\hline G001 & Nafsu makan berkurang \\
G002 & Demam \\
G003 & Diare \\
G004 & Batuk-batuk \\
G005 & Lemas \\
G006 & Munculnya tonjolan pada kulit \\
& perut \\
G007 & Kaki Nampak terbuka lebar \\
G008 & Adanya gangguan pernafasan \\
G009 & Tenggorokan bengkak \\
G010 & Urat-urat kuku dan lemah \\
G011 & Dari vagina keluar nanah \\
G012 & Sembelit \\
G013 & Gemetar \\
G014 & Lumpuh \\
G015 & Depresi \\
G016 & Muntah-muntah \\
G017 & Pucat \\
G018 & Pertumbuhan terganggu \\
G019 & Kehilangan berat badan \\
G020 & Babi banyak berbaring \\
\hline &
\end{tabular}

Tabel 2 Fakta Penyakit

\begin{tabular}{ll}
\hline Kode & Penyakit \\
\hline P001 & Cholera babi \\
P002 & Influenza babi \\
P003 & Pox babi \\
P004 & TBC babi \\
P005 & Pneumonia mikroplasma babi \\
P006 & Wabah babi \\
P007 & Leptospirosis \\
P008 & Antrax \\
P009 & Agalactia \\
P010 & Demam Afrika \\
P011 & Infeksi \\
P012 & Pleuropneumonia \\
P013 & Psedorabies \\
P014 & Anemia \\
P015 & Rheumatik \\
P016 & Erysipelas \\
P017 & Gastroenteritis menular \\
P018 & Enteritis Colibacillosis \\
\hline
\end{tabular}

\section{Entity Relationship Diagram}

Perancangan database mengenai aplikasi sistem pakar untuk mendeteksi penyakit pada ternak babi dapat dilihat dalam gambar UML seperti pada gambar 4 dan 5 dibawah ini..
Tabel 3 Basis Aturan Penyakit

\begin{tabular}{|c|c|}
\hline No & Basis Aturan Fuzzy Tsukam \\
\hline 1 & IF R1 AND G019 Tinggi AND G020 \\
\hline 2 & $\begin{array}{l}\text { IF R1 AND G004 Sering AND G008 } \\
\text { Ya AND G019 Ya THEN P4 }\end{array}$ \\
\hline 3 & $\begin{array}{l}\text { IF R2 AND G004 Sering AND G008 } \\
\text { Ya AND G015 Ya THEN P12 }\end{array}$ \\
\hline 4 & $\begin{array}{l}\text { IF R2 AND G009 Ya AND G010 } \\
\text { Ya THEN P8 }\end{array}$ \\
\hline 5 & IF R2 AND G005 Ya THEN P1 \\
\hline 6 & $\begin{array}{l}\text { IF R2 AND G004 Sering AND G005 } \\
\text { AND G008 Ya THEN P2 }\end{array}$ \\
\hline 7 & $\begin{array}{l}\text { IF R2 AND G004 Sering AND G005 } \\
\text { Ya AND G007 Ya AND G008 Ya } \\
\text { THEN P5 }\end{array}$ \\
\hline 8 & IF R3 AND G005 Ya THEN P7 \\
\hline 9 & $\begin{array}{l}\text { IF R3 AND G008 Ya AND G012 } \\
\text { Sering THEN P10 }\end{array}$ \\
\hline 10 & $\begin{array}{l}\text { IF R3 AND G008 Ya AND G013 } \\
\text { Sering AND G015 Ya AND G016 } \\
\text { Sering THEN P13 }\end{array}$ \\
\hline 11 & IF R3 AND G011 Ya THEN \\
\hline 12 & $\begin{array}{l}\text { IF R4 AND G017 Ya AND G018 Ya } \\
\text { AND G019 Tinggi THEN P14 }\end{array}$ \\
\hline 13 & $\begin{array}{l}\text { IF R4 AND G016 Sering AND G020 } \\
\text { Sering THEN P18 }\end{array}$ \\
\hline 14 & $\begin{array}{l}\text { IF R5 AND G016 Sering AND G019 } \\
\text { Tinggi AND G020 Sering THEN } \\
\text { P17 }\end{array}$ \\
\hline 15 & IF G001 Ya THEN R1 \\
\hline 16 & $\begin{array}{l}\text { IF G001 Ya AND G002 Ya THEN } \\
\text { R2 }\end{array}$ \\
\hline 17 & $\begin{array}{l}\text { IF G001 Ya AND G002 Ya AND } \\
\text { G003 Ya THEN R3 }\end{array}$ \\
\hline 18 & IF G003 Ya THEN R4 \\
\hline 19 & $\begin{array}{l}\text { IF G001 Ya AND G003 Ya THEN } \\
\text { R5 }\end{array}$ \\
\hline
\end{tabular}

Perancangan Antarmuka

Antarmuka pemakai digunakan pada lingkungan pengembangan oleh perekayasa pengetahuan untuk menyimpan pengetahuan dalam basis pengetahuan 


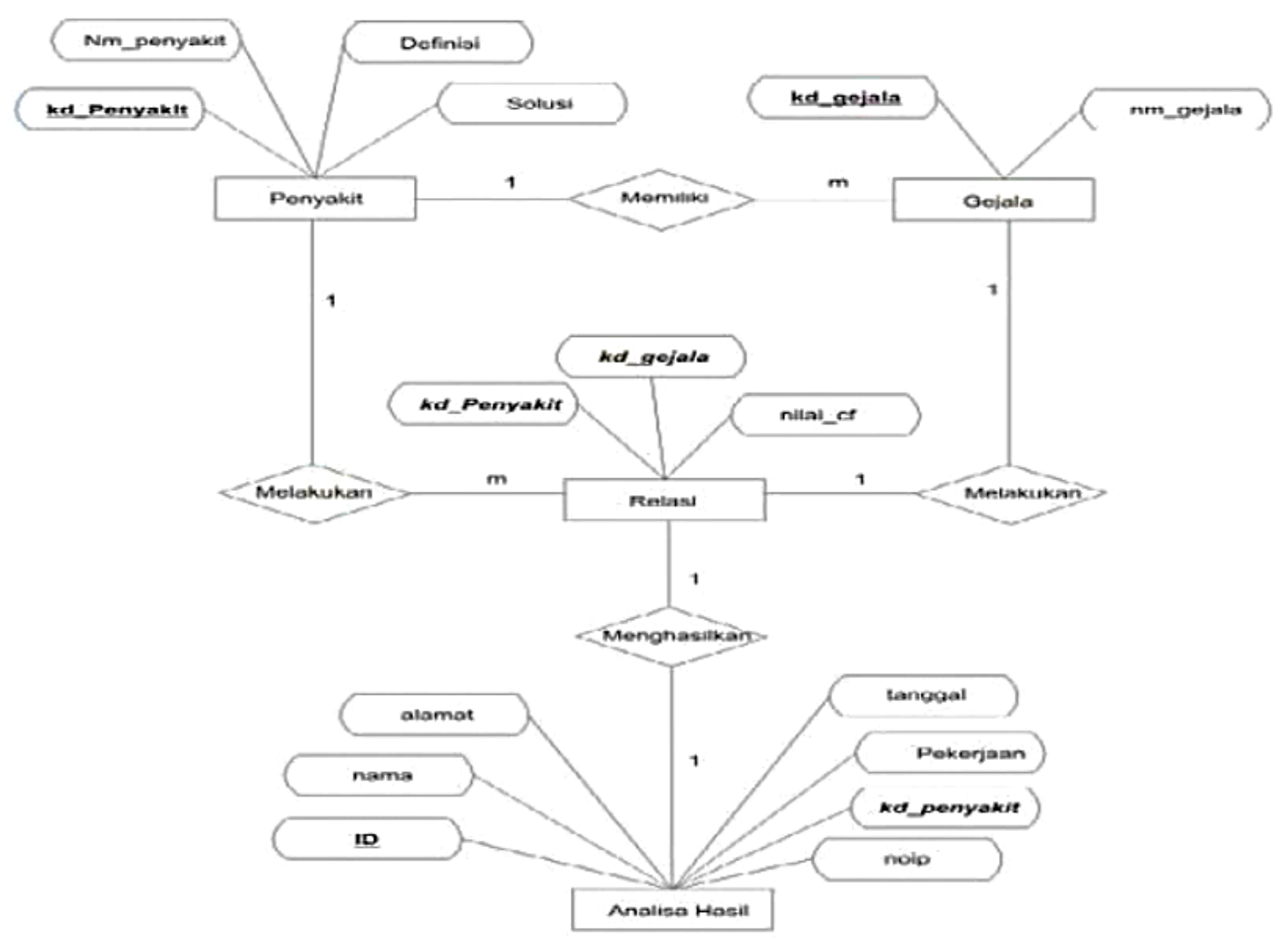

Gambar 4. Rancangan ERD

\begin{tabular}{|c|c|}
\hline no & int \\
\hline bd_Eejala__wal & $\begin{array}{l}\text { varchar } \\
\text { (5) }\end{array}$ \\
\hline statue & $\begin{array}{l}\text { verchar } \\
\text { (5) }\end{array}$ \\
\hline kodf_Eejala (F-K) & $\begin{array}{l}\text { verthar } \\
\text { (5) }\end{array}$ \\
\hline kode_penyakt (FK) & $\begin{array}{l}\text { verthar } \\
\text { (5) }\end{array}$ \\
\hline
\end{tabular}

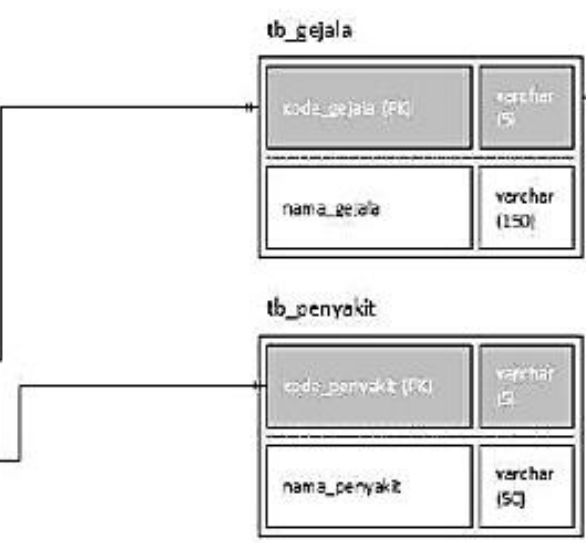

\begin{tabular}{|c|c|}
\hline Hetmone ifsis & - int \\
\hline 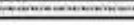 & 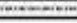 \\
\hline parcwerd & $\begin{array}{l}\text { varchar } \\
\text { (9) }\end{array}$ \\
\hline nama_krgkap & $\begin{array}{l}\text { varchar } \\
\text { (5D) }\end{array}$ \\
\hline telepen & $\begin{array}{l}\text { vschar } \\
\text { (13) }\end{array}$ \\
\hline
\end{tabular}

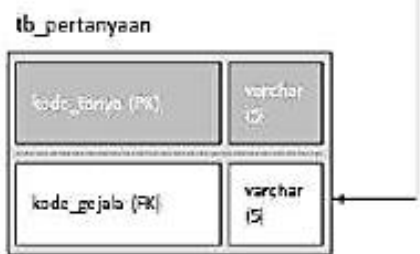

Gambar 5. Konseptual Database 


\section{Struktur Database}

Pengetahuan mengenai penyakit yang diperoleh pada proses representasi pengetahuan diimplementasikan dalam bentuk rancangan tabel dengan struktur seperti pada tabel 4 .

Tabel 4 Struktur tb_penyakit

\begin{tabular}{clll}
\hline No & $\begin{array}{l}\text { Nama Field } \\
\text { Panjang Field }\end{array}$ & $\begin{array}{l}\text { Tipe } \\
\text { Keterangan }\end{array}$ \\
\hline 1 & $\begin{array}{l}\text { Kode_penyakit } \\
\text { Primary Key }\end{array}$ & Varchar 5 \\
2 & Nama_penyakit & Varchar 255
\end{tabular}

Pengetahuan mengenai fase yang diperoleh pada proses representasi pengetahuan diimplementasikan dalam bentuk rancangan tabel dengan struktur seperti pada tabel 5. Bobot merupakan persentase pengaruh setiap fase terhadap hasil diagnosa penyakit

Tabel 5 Struktur tb status

\begin{tabular}{clll} 
No & $\begin{array}{l}\text { Nama Field } \\
\text { Panjang Field }\end{array}$ & $\begin{array}{l}\text { Tipe } \\
\text { Keterangan }\end{array}$ & Field \\
\hline 1 & $\begin{array}{l}\text { Kode_status } \\
\text { Primary Key }\end{array}$ & Varchar 5 \\
& $\begin{array}{l}\text { Primar 255 } \\
2\end{array}$ & Nama_status & Varchar 25 \\
3 & Bobot Decimal 4,2 & \\
\hline
\end{tabular}

Pengetahuan mengenai gejala yang diperoleh pada proses representasi pengetahuan diimplementasikan dalam bentuk rancnagan tabel 6 .

Tabel 6 Struktur tb_status

\begin{tabular}{cll}
\hline No & $\begin{array}{l}\text { Nama Field } \\
\text { Panjang Field }\end{array}$ & $\begin{array}{l}\text { Tipe } \\
\text { Keterangan }\end{array}$ \\
\hline 1 & $\begin{array}{l}\text { Kode_gejala } \\
\text { Primary Key }\end{array}$ & Varchar 5 \\
2 & Nama_gejala & Text \\
3 & Pertanyaan & Text \\
4 & Ket_gejala & Text \\
5 & Status Enum & \\
\multicolumn{4}{c}{ 'pasti','fuzzy' } \\
6 & Flag Enum \\
7 & 'kunci,'terkait', 'tidak' \\
8 & Kode_gejala_kunci Varchar5 \\
Kode_status & Varchar 5 \\
\hline
\end{tabular}

Gejala yang ditanyakan oleh sistem kepada peternak diberikan dalam bentuk pertanyaan yang disertai dengan keterangan dari gejala yang ditanyakan (ket_gejala). Status menunjukkan gejala bernilai pasti atau fuzzy. Flag menunjukkan suatu gejala yang merupakan gejala kunci terhadap gejala yang lain atau suatu gejala yang terkait dengan gejala kunci atau suatu gejala bukan merupakan gejala kunci dan terkait. Gejala kunci dari gejala terkait akan disimpan di kolom kode_gejala_kunci. Gejala sindrom dihubungkan dengan fase dimana gejala ini disimpan di kode_status.

Tabel 7 Struktur tb_terkait

\begin{tabular}{clll}
\hline No & $\begin{array}{l}\text { Nama Field } \\
\text { Panjang Field }\end{array}$ & $\begin{array}{l}\text { Tipe } \\
\text { Keterangan }\end{array}$ & Field \\
\hline 1 & $\begin{array}{l}\text { Kode_terkait } \\
\text { Primary Key }\end{array}$ & Varchar 5 \\
2 & Kode_gejala & Varchar 5 \\
3 & Kode_himpunan & Varchar 5 \\
\hline
\end{tabular}

Pada pemodelan gejala bernilai pasti dan gejala yang merupakan sindrom di bab sebelumnya, dimana kedua gejala ini dimodelkan dalam bentuk dua jenis himpunan ('Ya' dan 'Tidak'), dimana kedua jenis himpunan ini tidak mempunyai kurva sehingga batas bawah dan atas dari kurva diisikan dengan nilai 0 . Pada pemodelan gejala bernilai fuzzy dimodelkan dalam bentuk himpunan fuzzy dengan kurva keanggotaannya. Himpunan yang terbentuk untuk gejala bernilai fuzzy antara lain 'Tidak', 'Sangat Rendah', 'Rendah', 'Normal','Tinggi', 'Sangat Tinggi'. Setiap himpunan mempunyai suatu jenis kurva tertentu seperti 'Linier Turun', 'Segitiga', 'Linier Naik',

Pengetahuan mengenai himpunan dari gejala bernilai 'fuzzy' diimplementasikan dalam bentuk tabel berikut:

Tabel 8 Struktur tb_himpunan

\begin{tabular}{clll}
\hline No & $\begin{array}{l}\text { Nama Field } \\
\text { Panjang Field }\end{array}$ & $\begin{array}{l}\text { Tipe } \\
\text { Keterangan }\end{array}$ \\
\hline 1 & $\begin{array}{l}\text { Kode_himpunan } \\
\text { Primary Key }\end{array}$ & Varchar 5 \\
2 & Nama_penyakit & Varchar 255 \\
\hline
\end{tabular}

Tabel 9 Struktur tb_kurva

\begin{tabular}{cll}
\hline No & $\begin{array}{l}\text { Nama Field } \\
\text { Panjang Field }\end{array}$ & $\begin{array}{l}\text { Tipe } \\
\text { Keterangan }\end{array}$ \\
\hline 1 & $\begin{array}{l}\text { Kode_kurva } \\
\text { Primary Key }\end{array}$ & Varchar 5 \\
2 & Nama_kurva & Varchar 255 \\
\hline
\end{tabular}

Tabel 10 Struktur tb_gejala_fuzzy

\begin{tabular}{clll}
\hline No & Nama Field & \multicolumn{1}{l}{ Tipe } & Field \\
& Panjang Field & \multicolumn{1}{l}{ Keterangan } \\
\hline 1 & Kode_gejala_fuzzy & Varchar \\
& 6 & Primary Key & \\
2 & Kode_gejala & Varchar 5 \\
3 & Kode_himpunan & Varchar 5 \\
4 & Batas_bawah & Decimal 11,2 \\
\hline
\end{tabular}




\begin{tabular}{|c|c|c|c|}
\hline 5 & Batas_atas & Decimal & 11,2 \\
\hline 6 & Kode_kurva & Varchar & 5 \\
\hline 7 & Jenis_kelamin & Enum & 'tidak \\
\hline \multicolumn{4}{|c|}{ mempengaruhi', 'jantan', 'betina' } \\
\hline 8 & $\begin{array}{l}\text { Batas_bawah_use } \\
11,2\end{array}$ & & Decimal \\
\hline 9 & Batas_atas_user & Decimal & 11,2 \\
\hline
\end{tabular}

Representasi jawaban peternak terhadap gejala pasti diimplementasikan kedalam rancangan tabel berikut.

Tabel 11 Struktur tb_pilihan

\begin{tabular}{clll}
\hline No & $\begin{array}{l}\text { Nama Field } \\
\text { Panjang Field }\end{array}$ & $\begin{array}{l}\text { Tipe } \\
\text { Keterangan }\end{array}$ \\
\hline 1 & Kode_pilihan & Varchar 5 \\
& Primary Key & \\
2 & Nama_pilihan & Varchar 255 \\
3 & Nilai Decimal 4,2 & \\
\hline
\end{tabular}

\section{PengujianAplikasi}

Evaluasi sistem ini diukur berdasarkan uji penerapan sistem dalam kasus nyata. Untuk pengujian hewan ternak dilakukan di daerah Mengwi, Badung, Bali. Proses uji pertama dilakukan dengan cara pakar mendiagnosis terlebih dahulu baru kasus diujikan dengan sistem. Dari 20 kasus hanya mendapat 5 diagnosa penyakit yaitu influenza babi, TBC babi, wabah, anemia dan infeksi pada babi. Sedangkan 15 kasus lain tidak didapatkan. Nilai ketepatan dari konsultasi penyakit pada ternak babi didapatkan dari nilai rata-rata keberhasilan sistem menemukan penyakit pada babi yaitu $85 \%$.

Tabel 12 Uji Aplikasi

\begin{tabular}{|c|c|c|c|c|c|}
\hline K & DP & JK & DS & JK & Ke \\
\hline 1 & $\begin{array}{l}\text { Influenza } \\
\text { babi }\end{array}$ & 5 & $\begin{array}{l}\text { Influenza } \\
\text { babi }\end{array}$ & 5 & $100 \%$ \\
\hline 2 & Wabah & 3 & Wabah & 3 & $90 \%$ \\
\hline 3 & Infeksi & 3 & Infeksi & 5 & $85 \%$ \\
\hline 4 & $\begin{array}{l}\text { TBC } \\
\text { babi }\end{array}$ & 4 & $\begin{array}{l}\text { TBC } \\
\text { babi }\end{array}$ & 4 & $80 \%$ \\
\hline 5 & $\begin{array}{r}\text { Anemia } \\
\text { Juta-rata } 1\end{array}$ & $\begin{array}{l}5 \\
\text { llah } \\
\text { ateg }\end{array}$ & Anemia & $\begin{array}{l}4 \\
20\end{array}$ & $\begin{array}{l}70 \% \\
425 \% \\
85 \%\end{array}$ \\
\hline
\end{tabular}

Keterangan:

$\mathrm{K}$ : Kasus

DP: Diagnosa Pakar

JK : Jumlah Kasus

DS : Diagnosa Sistem

Ke : Ketepatan

\section{SIMPULAN}

Kesimpulan dari penelitian awal penelitian tentang pengembangan aplikasi sistem pakar untuk mendeteksi penyakit pada ternak babi, yaitu:

1.Sistem pakar untuk diagnosa penyakit babi telah dikembangkan dengan menggabungkan metode logika fuzzy dan faktor kepastian untuk menangani ketidakpastian gejala yang dialami oleh ternak babi dan ketidakmampuan seorang pakar dalam mendefinisikan hubungan antara gejala dan penyakit secara pasti. Nilai ketepatan dari konsultasi penyakit pada ternak babi didapatkan dari nilai rata-rata keberhasilan sistem menemukan penyakit pada babi yaitu $85 \%$.

2.Pengetahuan berupa fakta mengenai penyakit yang diperoleh melalui proses akusisi pengetahuan direpresentasikan ke dalam bentuk pemodelan himpunan bernilai pasti dan himpunan bernilai fuzzy. Pengetahuan berupa aturan direpresentasikan ke dalam bentuk sistem produksi IF... Then.

\section{DAFTAR PUSTAKA}

[1] F. F. X. X. Z. Zetian, "Pig-vet: A webbased expert system for pig disease diagnosis," Expert Systems with Applications, vol. 29, no. 1, pp. 93-103, 2005.

[2] L. X. G. Han, "An IDSS Supported by Semantic Technology: a Study for Pig Disease Diagnosis Management.," in 6th IEEE International Conference on Software Engineering and Service Science (ICSESS), IEEE, 2015.

[3] I. P. D. Ardana, Ternak Babi Manajemen Reproduksi, Produksi, dan Penyakit, Denpasar: Udayana University Press, 2015.

[4] S. S. S. D. S. Sivanandam, Introduction to Fuzzy Logic using, New York: Springer, 2007.

[5] Kusrini, Sistem Pakar, Yogyakarta: Andi Ofset, 2008.

[6] S. P. H. Kusumadewi, Aplikasi Logika Fuzzy untuk Pendukung Keputusan Edisi ke 2, Yogyakarta: Graha Ilmu, 2010. 
[7] S. Kusumadewi, Artificial Intelligence

(Teknik dan Aplikasinya)., Yogyakarta: Graha Ilmu, 2003. 